\title{
PITPNC1 Gene
}

National Cancer Institute

\section{Source}

National Cancer Institute. PITPNC1 Gene. NCI Thesaurus. Code C101626.

This gene plays a role in both signaling and lipid transport. 